\title{
IMPACT OF SELECTING DIFFERENT REFERENCE SPECTRA ON ERRORS IN DOAS ANALYSIS
}

\author{
Adrian Roșu*, Daniel-Eduard Constantin, Bogdan Roşu, Maxim Arseni, \\ Mirela Voiculescu, Cătalina Iticescu and Lucian Puiu Georgescu \\ "Dunarea de Jos" University of Galati, Faculty of Sciences and Environment, European Centre of \\ Excellence for the Environment, Domneasca Street, no. 111, 800201, Galati, Romania; \\ *Corresponding author: rosu_adrian_90@yahoo.ro
}

\begin{abstract}
This paper presents an analysis of various sources of errors for measurements of atmospheric trace gases concentrations, based on DOAS (Differential Optical Absorption Spectroscopy). The error analysis is based on measurements done in Galati city on 11 October 2018. The spectral window was 425-490 nm which is used for $\mathrm{NO}_{2}$ detection in the lower atmosphere. Two sets of reference spectra were used: one recorded during a measurement campaign of the project DANS in Galati city and one recorded in May 2015 in a remote area at high altitudes, where $\mathrm{NO}_{2}$ sources are scarce. This investigation will provide a more reliable method of reducing the errors in $\mathrm{NO}_{2}$ DOAS spectral analysis by selecting appropriate reference spectra.
\end{abstract}

Keywords: DOAS technique, mobile DOAS measurements, DOAS analysis, air pollution

\section{INTRODUCTION}

Nitrogen dioxide $\left(\mathrm{NO}_{2}\right)$ is an important trace gas in the atmosphere, which, together with nitrogen monoxide $(\mathrm{NO})$, is known as nitrogen dioxides $\left(\mathrm{NO}_{\mathrm{x}}\right)$. Trace gasses regulate and participate in many chemical reaction in the lower layers of the atmosphere (stratosphere and troposphere). Nitrogen oxides are very important chemical species that are precursors in formation of ozone trough photochemical reaction [1]. The $\mathrm{NO}_{\mathrm{x}}$ has strong influence on the concentration of $\mathrm{OH}$, therefore affecting the lifetime of methane and other gases [2]. $\mathrm{NO}_{2}$ is a minor trace gas but with an important indirect effect on climate change due to the cooling effect caused by the oxidation of the aerosols produced from burning of the fossil fuels [3]. Ozone destruction is mainly caused by the stratospheric $\mathrm{NO}_{2}$ that is formed from oxidation of $\mathrm{N} 2 \mathrm{O}$ [4]. Stratospheric $\mathrm{NO}_{2}$ also blocks the depletion of ozone by forming unreactive compounds like $\mathrm{ClONO}_{2}$ and $\mathrm{HNO} 3$ [5]. In the troposphere, $\mathrm{NO}_{2}$ can represent more than $90 \%$ of the total column in polluted regions where it's density on column can overpass $3 \times 10^{16}$ molec. $/ \mathrm{cm}^{2}[6]$.

Because of the importance of the $\mathrm{NO}_{2}$ in the atmosphere chemistry and changes that occurs between the atmosphere layers it is important that concentrations and distribution on a global scale are measured on a regular basis, and use accurate methods. Today, observations of $\mathrm{NO}_{2}$ at global scale are obtained by using equipmenta mounted on satellites alongside with complementary ground based observations, based on DOAS technique (Differential Optical Absorption Spectroscopy), to obtain a clearer image on how much is polluted the air with this trace gas. $\mathrm{NO}_{2}$ column densities have been 
retrieved using DOAS technique from space since the mid-90s from the nadir-viewing UV/Vis instruments like: GOME [7], SCIAMACHY [8], OMI [9] and the GOME-2 instruments aboard MetOp-A and MetOp-B [10]. Nowadays, space observations are made with the most advanced space instrument called TROPOMI launched in October 2018 that will extend the record of these observations [11]. In order to sustain and validate these space observations an upwards image of the density of $\mathrm{NO}_{2}$ columns is needed this is achieved by using airborne and ground based mobile DOAS systems (components of similar system is presented in the next section) during measurement campaigns like AROMAT [12]. Mobile DOAS measurements were recently used over South-East of Europe, to confirm or validate satellite measurements or to identify possible sources and variation of $\mathrm{NO}_{2}$ pollution $[13,14,15,16]$.

In order to have a reliable support from ground-based measurements detailed tests are needed, as well as evaluation of the results of each step of the retrieval of $\mathrm{NO}_{2}$ columnar densities. Here we present a preliminary experiment on the first step of retrieval for $\mathrm{NO}_{2}$ DSCD (Differential Slant Column Densities) by testing how the reference spectra can affect the result of spectral analysis of the mobile DOAS measurements performed in Galati city on 11 October 2018.

\section{EXPERIMENTAL}

Mobile DOAS measurements were performed in Galati city on 11 October 2018. The DOAS technique is based on Beer-Lambert law applied in free atmosphere, which describes the absorption of the sunlight by the atmospheric trace gasses. In order to perform a spectral analysis it is mandatory to use a high resolution spectral footprint of the trace gas; this is usually recorded in the laboratory in a steady state conditions [17] and an example is shown in Fig. 1. This footprint was used in the spectral analysis where we used the spectra recorded in the window between $425-440 \mathrm{~nm}$ (red rectangle in Fig. 1).

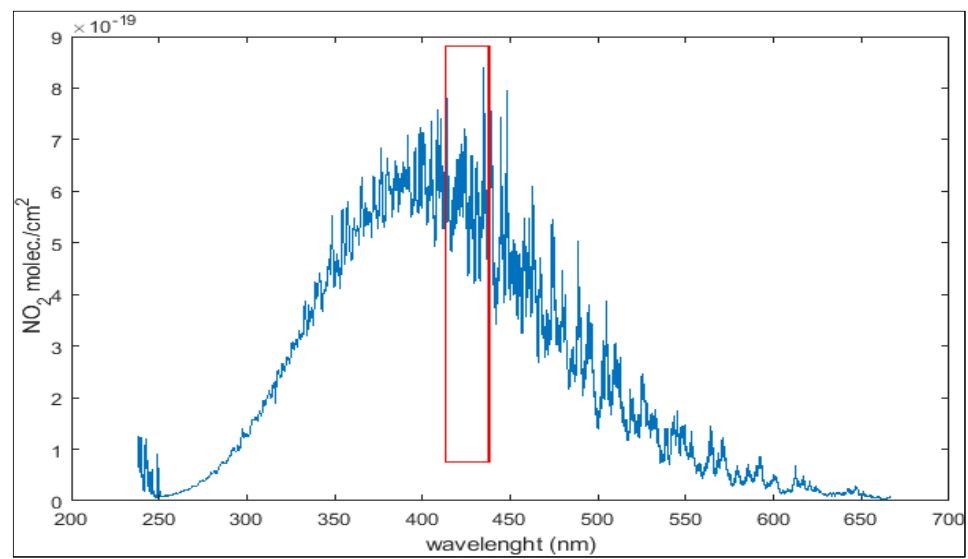

Fig. 1. High resolution for $\mathrm{NO}_{2}$ absorbtion spectral footprint (cross section bettwen the red rectangle was used as a setting in spectral analisys [17] 


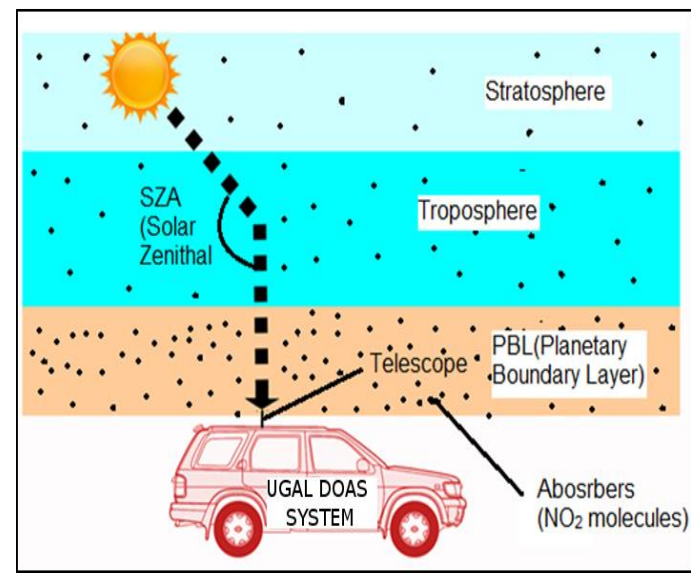

Fig. 2.a) The principle of mobile DOAS observations; b) The UGAL DOAS mobile system

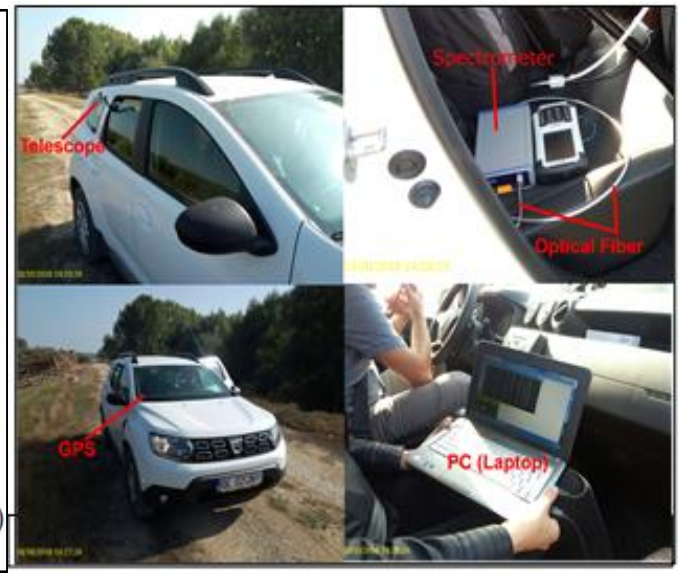

Fig. 2.a) The principle of mobile DOAS observations; b) The UGAL DOAS mobile system components [14, 15]

The principle of the mobile DOAS method can be seen in Fig. 2a where the mobile DOAS system is recording sunlight spectra in zenith geometry and is mounted on a car. The UGAL DOAS mobile system used in our measurements is shown in Fig. 2b. The car contains the entire DOAS system, consisting of an optical fiber with a telescope mounted on the rear back window viewing the zenith, a GPS (for acquisition of the location of the system), a PC (for spectra recording and data analysis was used a laptop) and a spectrometer (Avantes ULS2048XL Starline, with a spectral resolution of $0.7 \mathrm{~nm}$ and a spectral domain ranging from $295-550 \mathrm{~nm}$ ). The whole DOAS system setup can be observed in Figure 2b. Each DOAS determination is spatially referenced using the coordinates recorded by a mouse GPS model BR-355S4. All the data recorded is sent to a PC where the data is stored $[13,14,15,16,18])$.

All spectra recorded during the measurement campaign were analyzed using QDOAS software developed by BIRA-IASB (The Royal Belgian Institute for Space Aeronomy) [19]. The $\mathrm{NO}_{2}$ spectral analysis requires additional information about other atmospheric components $\left(\mathrm{O}_{4}\right.$, Ring effect, in order to exclude other spectral interferences, optical and instrumental effects on recorded spectra (see Table 1).

Table 1 QDOAS settings for $\mathrm{NO}_{2}$ DSCD retrieval

\begin{tabular}{|c|c|c|}
\hline \multicolumn{3}{|c|}{$\mathrm{NO}_{2}$ settings and absorption cross sections used } \\
\hline Molecule & Temperature & Reference \\
\hline $\mathrm{NO}_{2}$ & $298 \mathrm{~K}$ & {$[17]$} \\
\hline $\mathrm{O}_{3}$ & $293 \mathrm{~K}$ & {$[20]$} \\
\hline $\mathrm{O}_{4}$ & $293 \mathrm{~K}$ & {$[21]$} \\
\hline $\mathrm{Ring}$ & & NDSC [22] \\
\hline $\mathrm{H}_{2} \mathrm{O}$ & $296 \mathrm{~K}$ & {$[23]$} \\
\hline Wavelength range & $425-490 \mathrm{~nm}$ \\
\hline Polynomial order & 5 & \\
\hline
\end{tabular}

One of the most important features in the QDOAS analysis is the reference spectra ( $\mathrm{SCD}_{\text {ref }}$ ) (see Fig. 3). The $\mathrm{SCD}_{\text {ref }}$ is basically a spectrum measured with the same system but assuming that no $\mathrm{NO}_{2}$ sources exist in the area (i.e. pollution sources). The $\mathrm{SCD}_{\text {ref }}$ presented in Fig. 3 as a red line was recorded on 1 May 2015, close to Sebeș city in Transilvania, Romania. The other two $\mathrm{SCD}_{\text {ref }}$ (represented in Fig. 3 as green and bluelines) were recorded on 11 Octomber 2018 in Galati city, at 10 $\mathrm{AM}$ and $12 \mathrm{PM}$ local time (LT). 


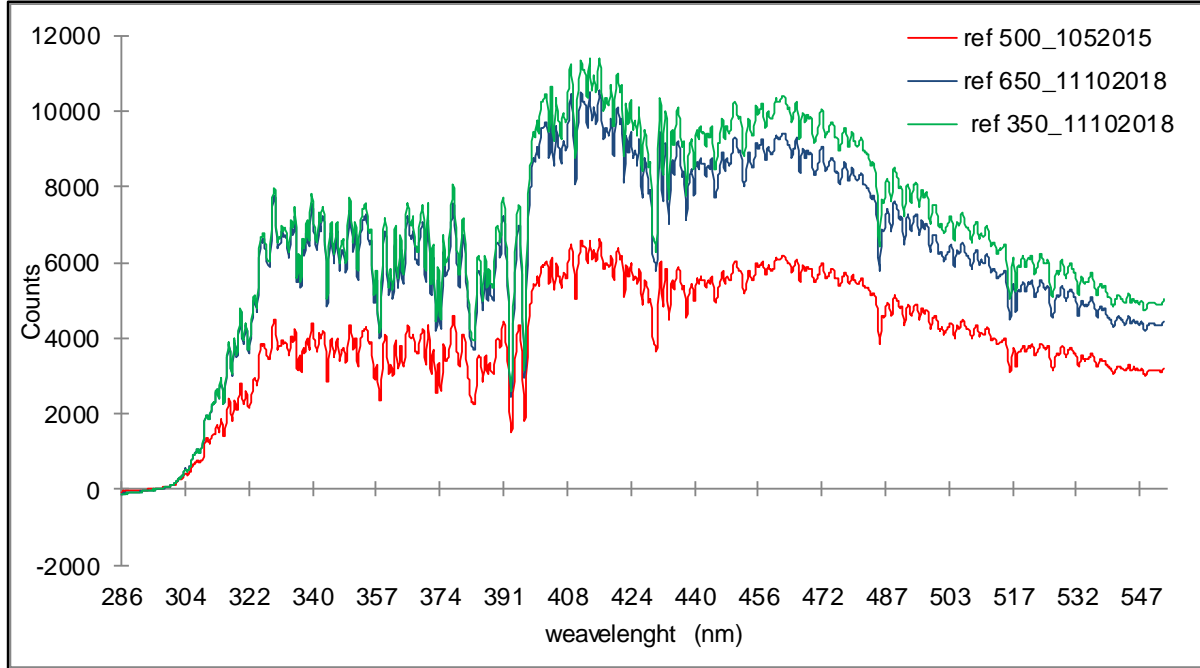

Fig. 3. The three reference spectra used in the QDOAS analisys of mobile DOAS measurement performed in Galați city in 11 October 2019. expression:

The total measured slant column density $\left(\mathrm{SCD}_{\mathrm{tot}}\right)$ is calculated using the following

$$
S C D_{t o t}=D S C D+S C D_{r e f}
$$

\section{RESULTS AND DISCUSSION}

The results of our measurements, i.e. the DSCD for $\mathrm{NO}_{2}$ (a) and the associated errors (b) , are shown in Fig. 4. When a reference spectrum from a remote area is used, the densities are clearly higher, but also the associated errors increase. This is seen mostly during the first period of the measurement (morning), before the spikes most likely associated with traffic increase.

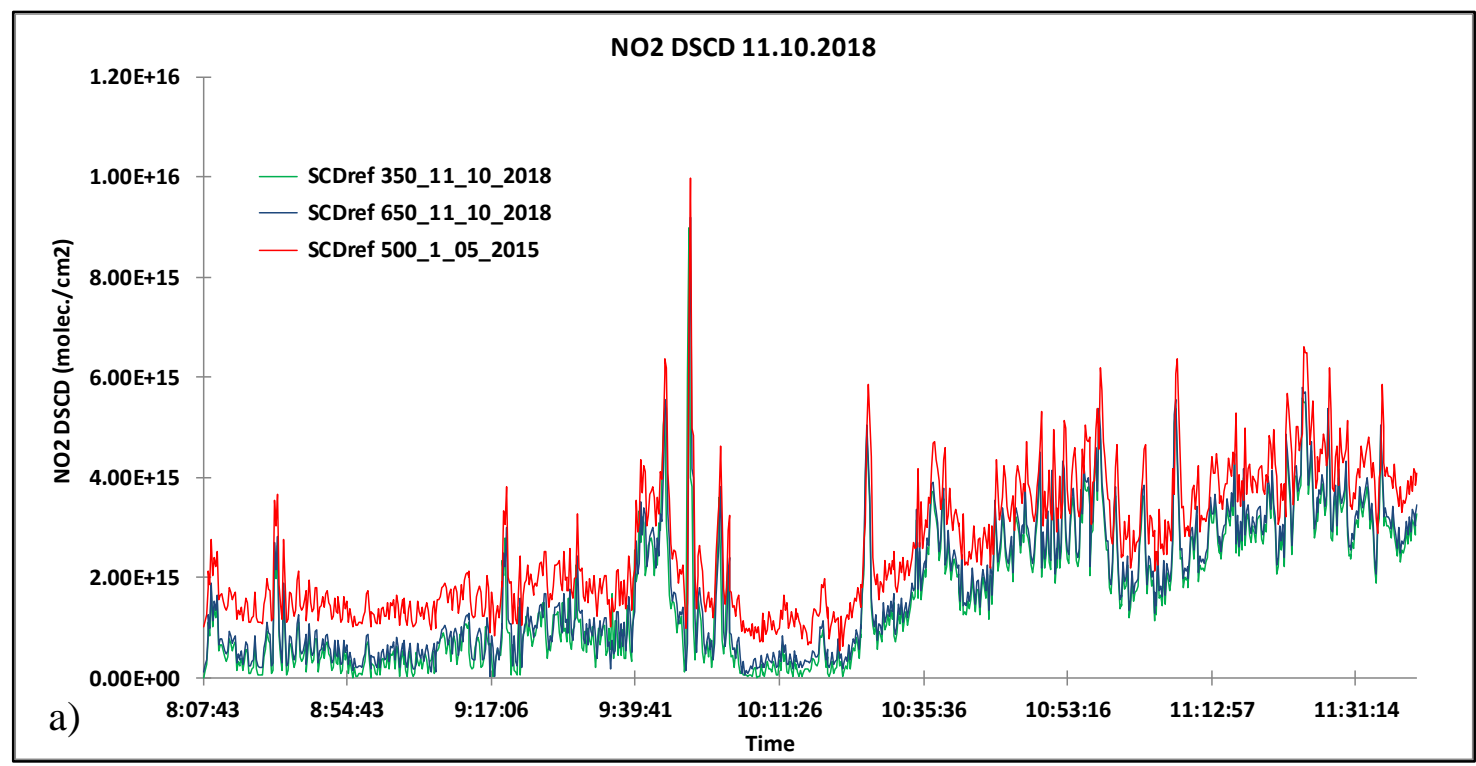




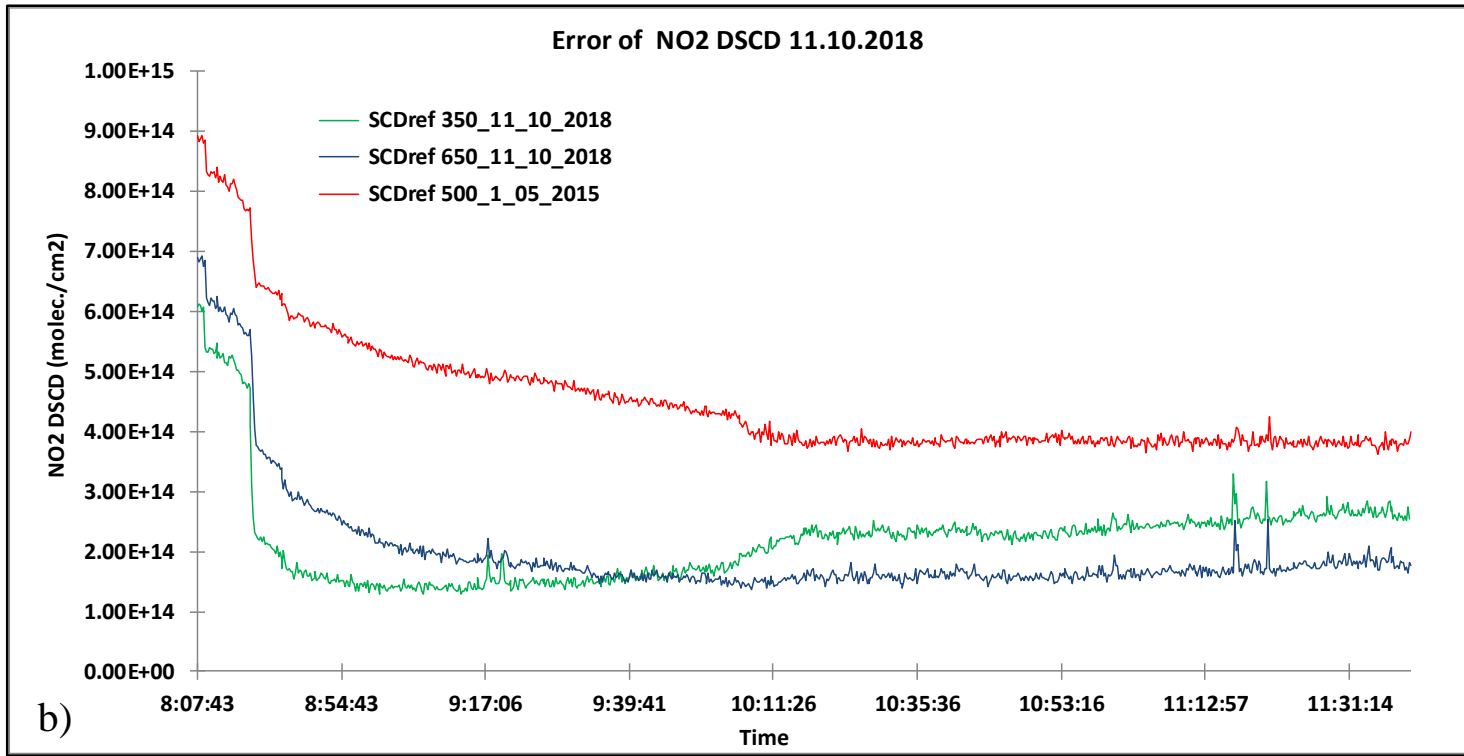

Fig. 4. Results of QDOAS analysis of mobile DOAS measurements performed on 11 October 2018 in Galați city using different reference spectra (results obtained by using SCD ref 500 represented with red line; results obtained by using $S C D_{\text {ref }} 350$ represented with green line; results obtained by using $S C D_{\text {ref }} 650$ represented with blue line): a) $\mathrm{NO}_{2} \mathrm{DSCD}$ and b) $\mathrm{NO}_{2}$ DSCD errors.

The error analysis for measurements made on 11 October 2018 in Galati can be seen in table 2. Choosing an appropriate $\mathrm{SCD}_{\text {ref }}$ will definitely improve the results about the $\mathrm{NO}_{2}$ content given as $\mathrm{SCD}_{\text {tot }}$ (Total Slant Column Density). Also, using a $\mathrm{SCD}_{\text {ref }}$ recorded in the same day of the measurements will clearly reduce the error of the $\mathrm{NO}_{2} \mathrm{DSCD}$, especially when measured around noon (12 PM), when the solar light path is shorter

Table 2. Errors of $\mathrm{NO}_{2}$ DSCD resulted from spectral analysis with different refference spectras

\begin{tabular}{|c|c|c|c|c|c|c|}
\hline $\begin{array}{c}\text { SCDref used } \\
\text { in QDOAS } \\
\text { analysis }\end{array}$ & \multicolumn{2}{|c|}{ SCD $_{\text {ref }} 350$} & \multicolumn{2}{|c|}{ SCDref 650} & \multicolumn{2}{|c|}{ SCD $_{\text {ref }} 500$} \\
\hline $\begin{array}{c}\text { Date of } \\
\text { aquisition }\end{array}$ & \multicolumn{2}{|c|}{ 11-Oct-18 } & \multicolumn{2}{|c|}{$11-$ Oct-18 } & \multicolumn{2}{|c|}{ 1-May-15 } \\
\hline $\begin{array}{c}\text { Time of } \\
\text { aquisition }\end{array}$ & \multicolumn{2}{|c|}{$10: 28$} & \multicolumn{2}{|c|}{$12: 05$} & \multicolumn{2}{|c|}{$12: 02$} \\
\hline Location & \multicolumn{2}{|c|}{ Galati } & \multicolumn{2}{|c|}{ Galati } & \multicolumn{2}{|c|}{ Sebeș } \\
\hline $\begin{array}{l}\text { QDOAS } \\
\text { results }\end{array}$ & $\begin{array}{c}\mathrm{NO}_{2} \\
\mathrm{DSCD}\end{array}$ & $\begin{array}{c}\mathrm{NO}_{2} \mathrm{DSCD} \\
\text { error }\end{array}$ & $\mathrm{NO}_{2} \mathrm{DSCD}$ & $\begin{array}{c}\mathrm{NO}_{2} \mathrm{DSCD} \\
\text { error }\end{array}$ & $\mathrm{NO}_{2} \mathrm{DSCD}$ & $\begin{array}{c}\mathrm{NO}_{2} \text { DSCD } \\
\text { error }\end{array}$ \\
\hline Average & $1.64 \mathrm{E}+15$ & $2.20 \mathrm{E}+14$ & $1.81 \mathrm{E}+15$ & $2.01 \mathrm{E}+14$ & $2.63 \mathrm{E}+15$ & $4.52 \mathrm{E}+14$ \\
\hline Min & $1.03 \mathrm{E}+12$ & $1.28 \mathrm{E}+14$ & $1.82 \mathrm{E}+13$ & $1.38 \mathrm{E}+14$ & $5.40 \mathrm{E}+14$ & $3.63 \mathrm{E}+14$ \\
\hline Max & $8.99 \mathrm{E}+15$ & $6.13 \mathrm{E}+14$ & $9.20 \mathrm{E}+15$ & $6.91 \mathrm{E}+14$ & $9.99 \mathrm{E}+15$ & $8.93 \mathrm{E}+14$ \\
\hline $\begin{array}{l}\text { Average } \\
\text { Error }\end{array}$ & \multicolumn{2}{|c|}{13.43} & \multicolumn{2}{|c|}{11.10} & \multicolumn{2}{|c|}{17.18} \\
\hline Min Error & \multicolumn{2}{|c|}{7.80} & \multicolumn{2}{|c|}{7.61} & \multicolumn{2}{|c|}{13.78} \\
\hline Max Error & \multicolumn{2}{|c|}{6.82} & \multicolumn{2}{|c|}{7.51} & \multicolumn{2}{|c|}{8.94} \\
\hline
\end{tabular}

The map of spatial distribution of each DOAS observation made on 11 October 2018 analysed with the $\mathrm{SCD}_{\text {ref }} 650$ (which gives the lowest error) are represented in the Fig. 5. Using this method for selecting an adequate $\mathrm{SCD}_{\text {ref }}$ the mean error for determination $\mathrm{NO}_{2} \mathrm{DSCD}$ using spectral analysis is reduced by $10 \%$ (case of $\mathrm{SCD}_{\text {ref }} 650$ ). In this way, the spatial representation of $\mathrm{NO}_{2}$ pollution described by $\mathrm{NO}_{2}$ DSCD is more reliable in showing the hot spots in the studied area. The results presented in Fig. 5 show that in Galati city the main sources of $\mathrm{NO}_{2}$ are located on the main 
streets where traffic jams can occur, another source can be seen in the North-East of the city probably we passed under the emission plume of the steel factory Arcelor Mittal.

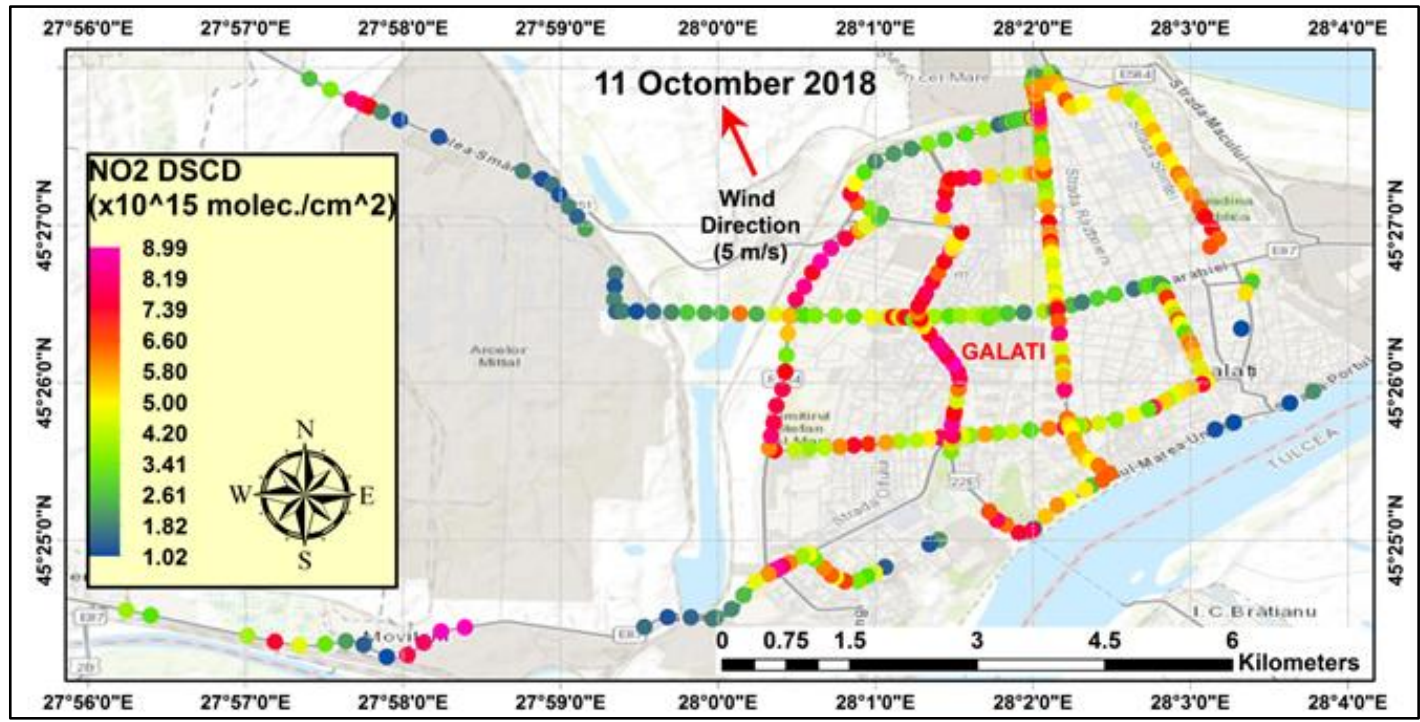

Fig. 5. Distribution map of the $\mathrm{NO}_{2} \mathrm{DSCD}$ resulted from measurements performed in Galati city on 11 October 2018, using SCDref 650

\section{CONCLUSIONS}

Results of the spectral analysis based on three different reference spectra shows that using reference spectra recorded in the same day and in the same location reduces the errors of $\mathrm{NO}_{2} \mathrm{DSCD}$. Unexpectedly, it is not the "cleanest" $\mathrm{SCD}_{\text {ref }}$ that gives the best results, but reference spectra that originates close to the measurement site. Based on our results we can conclude that using a $\mathrm{SCD}_{\text {ref }}$ recorded far from the measurements site introduces significant errors, thus reduces the reliability of a correct estimation of the $\mathrm{NO}_{2}$ pollution level. Using a $\mathrm{SCD}_{\text {ref }}$ recorded at high $\mathrm{SZA}$ (other period that around 12 PM LT, when light is passing almost vertically) can introduce moderate errors in the assumption of the $\mathrm{NO}_{2}$ DSCD resulted from spectral analysis using QDOAS software.

Acknowledgments: The work of Adrian Roșu and Daniel-Eduard Constantin was supported by the project ASSESS no. 150/2017, a grant of the Romanian Space Agency (ROSA-STAR). The work of Maxim Arseni, Cătalina Iticescu and Lucian Puiu Georgescu was supported by the project "Strategy and actions to prepare for national participation in the DANUBIUS-RI" acronym "DANS" financed by the Romanian Ministry of Research and Innovation.

\section{References}

1. Sillman, S., Logan, J. A., and Wofsy, S. C., The sensitivity of ozone to nitrogen oxides and hydrocarbons in regional ozone episodes, J. Geophys. Res., 95, 1837-1851, 1990.

2. Fuglestvedt, J. S., Berntsen, T., Isaksen, I. S. A., Mao, H., Liang, X.- Z., Wang, W.C., Climatic forcing of nitrogen oxides through changes in tropospheric ozone and methane, Atmos. Environ., 33, 961-977, 1999.

3. Shindell, D. T., Faluvegi, G., Koch, D. M., Schmidt, G. A., Unger, N., Bauer, S. E., Improved attribution of climate forcing to emissions, Science, 326, 716-718, 2009.

4. Hendrick, F., Mahieu, E., Bodeker, G. E., Boersma, K. F., Chipperfield, M. P., De Maziére, M., De Smedt, I., Demoulin, P., Fayt, C., Hermans, C., Kreher, K., Lejeune, B., Pinardi, G., Servais, C., Stübi, R., van der A, R., Vernier, J.-P., Van Roozendael, M., Analysis of 
stratospheric $\mathrm{NO}_{2}$ trends above Jungfraujoch using ground-based UV-visible, FTIR, and satellite nadir observations, Atmos. Chem. Phys., 12, 8851-8864, 2012.

5. Murphy, D. M., Fahey, D. W., Proffitt, M. H., Liu, S. C., Chan, K. R., Eubank, C. S., Kawa, S. R., Kelly, K. K., Reactive nitrogen and its correlation with ozone in the lower stratosphere and upper troposphere, J. Geophys. Res., 98, 8751-8773, 1993.

6. Van Geffen, J., Boersma, K. F., Van Roozendael, M., Hendrick, F., Mahieu, E., De Smedt, I., Veefkind, J. P., Improved spectral fitting of nitrogen dioxide from OMI in the 405--465 nm window. Atmospheric Measurement Techniques, 8(4), 1685-1699, 2015.

7. Burrows, J. P., Weber, M., Buchwitz, M., Rozanov, V., LadstätterWeißenmayer, A., Richter, A., Debeek, R., Hoogen, R., Bramstedt, K., Eichmann, K.-U., Eisinger, M., Perner, D., The Global Ozone Monitoring Experiment (GOME): Mission concept and first results, J. Atmos. Sci., 56, 151-175, 1999.

8. Bovensmann, H., Burrows, J. P., Buchwitz, M., Frerick, J., Noel, S., Rozanov, V. V., Chance, K. V., Goede, A. P. H., SCIAMACHY: Mission objectives and measurement modes, J. Atmos. Sci., 56, 127-150, 1999.

9. Levelt, P. F., van den Oord, G. H. J., Dobber, M. R., Mälkki, A., Visser, H., de Vries, J., Stammes, P., Lundell, J. O. V., Saari, H., The Ozone Monitoring Instrument, IEEE Trans. Geosci. Rem. Sens., 44, 1093-1101, 2006.

10. Munro, R., Eisinger, M., Anderson, C., Callies, J., Corpaccioli, E. Lang, R., Lefebvre, A., Livschitz, Y., Albinana, A. P., GOME-2 on MetOp, ESA publication SP 628, Paris, France, 2006.

11. Veefkind, J. P., Aben, I., McMullan, K., Förster, H., de Vries, J., Otter, G., Claas, J., Eskes, H. J., de Haan, J. F., Kleipool, Q., van Weele, M., Hasekamp, O., Hoogeveen, R., Landgraf, J., Snel, R., Tol, P., Ingmann, P., Voors, R., Kruizinga, B., Vink, R., Visser, H., Levelt, P. F., TROPOMI on the ESA Sentinel-5 Precursor A GMES mission for global observations of the atmospheric composition for climate, air quality and ozone layer applications, Remote Sens. Environ., 120, 70-83, 2012.

12. Carlos Meier, A., Schönhardt, A., Bösch, A., Richter, A., Seyler, A., Ruhtz, T., Constantin, D. E.,Shaiganfar, R., Wagner, T., Merlaud, A., Van Roozendael, M., Belegante, L., Nicolae, D., Georgescu, L. P., Burrows, J. P., High-resolution airborne imaging DOAS measurements of $\mathrm{NO}_{2}$ above Bucharest during AROMAT. Atmospheric Measurement Techniques, 10(5), 1831-1857, 2017

13. Rosu, A., Constantin, D. E., Georgescu, L., Air pollution level in europe caused by energy consumption and transportation. Journal of Environmental Protection and Ecology, 17(1), 1-8, 2016.

14. Rosu, A., Rosu, B., Arseni, M., Constantin, D. E., Voiculescu, M., Georgescu, L. P., van Roozendael, M., Tropospheric nitrogen dioxide measurements in South-East of Romania using zenith-sky mobile DOAS observations, TEHNOMUS - New Technologies and Products in Machine Manufacturing Technologies, No. 24, pp 189-194, 2017.

15. Roșu,A., Roșu, B., Constantin, D.E., Voiculescu, M., Arseni, M., Călmuc, V., Iticescu, C., Georgescu, L.P., Overview of $\mathrm{NO}_{2}$ and other trace gases pollution level in the lower DANUBE basin during DANS measurement campaign, Annals of "Dunarea de Jos" Univ. Galati, Fascicle II, Year X (XLI), No. 2, pp. 171-178, 2018.

16. Constantin, D. E., Merlaud, A., Voiculescu M., Van Roozendael, M., Arseni, M., Roșu, A., Georgescu, L.P., $\mathrm{NO}_{2}$ and $\mathrm{SO}_{2}$ observations in SouthEast Europe using mobile DOAS observations, Carpath. J. Earth Env., 12, no. 2, 323-328, 2017.

17. Roșu, A., Utilizarea tehnicii spectroscopiei optice de absorție diferențială în cuantificarea poluării atmosferice cu dioxid de azot (Doctoral dissertation, " Dunărea de Jos" Univ. Galaţi), Galați, 2018.

18. Vandaele, A. C., Hermans, C., Simon, P. C., Carleer, M., Colin, R., Fally, S., Coquart, B., Measurements of the $\mathrm{NO}_{2}$ absorption cross-section from $42000 \mathrm{~cm}-1$ to $10000 \mathrm{~cm}^{-1}(238-$ $1000 \mathrm{~nm}$ ) at $220 \mathrm{~K}$ and $294 \mathrm{~K}$, J. Quant. Spectrosc. Ra., 59(3-5), 171-184, 1998.

19. Danckaert, T., Fayt, C., van Roozendael, M., de Smedt, I., Letocart, V., Merlaud, A., Pinardi, G., Qdoas Software User Manual, Version 2.108, 2014. 
20. Bogumil, K., Orphal, J., Burrows, J. P., Temperature dependent absorption cross sections of $\mathrm{O}_{3}, \mathrm{NO}_{2}$, and other atmospheric trace gases measured with the SCIAMACHY spectrometer. In Proceedings of the ERS-Envisat-Symposium, Goteborg, Sweden, 2000.

21. Thalman, R., Zarzana, K. J., Tolbert, M. A., Volkamer, R., Rayleigh scattering cross-section measurements of nitrogen, argon, oxygen and air, J. Quant. Spectrosc. Ra., 147, 171-177, 2013.

22. CHance, K. V., Spurr, R. J. D., Ring effect studies: Rayleigh scattering, including molecular parameters for rotational Raman scattering, and the Fraunhofer spectrum, Appl. Optics, 36, 5224- 5230, 1997.

23. Rothman, L. S., Gordon, I. E., Barber, R. J., Dothe, H., Gamache, R. R., Goldman, A., Tennyson, J., HITEMP, the high-temperature molecular spectroscopic database. J. Quant. Spectrosc. Ra., 111(15), 2139-2150, 2010. 